\title{
Changing pattern of perforated PUD: Are NSAIDs to be blamed?
}

\author{
Ochonma Egwuonwu' ${ }^{1}$, Okoli Chinedu ${ }^{1}$, Gabriel Chianakwana ${ }^{1}$, Stanley Anyanwu ${ }^{1}$, Chiemelu Emegoakor ${ }^{1}$, Henry Nzeako ${ }^{1}$ \\ ${ }^{1}$ Department of Surgery, Nnamdi Azikiwe University Teaching Hospital, Nnewi, Nigeria
}

\begin{abstract}
Objective: This study aimed to determine if there is association between gastric perforation and non-steroidal anti-inflammatory drugs (NSAIDs) abuse in patients presenting with perforated peptic ulcer disease (PPUD).

Material and Methods: The data were collected retrospectively from May 2011 to May 2015 and then prospectively until December 2017. Sixty patients diagnosed with PPUD on exploratory laparotomy were evaluated. Data were analyzed using SPSS (version 21.0). P value $\leq 0.05$ was considered significant.

Results: A total of 60 patients were operated on for PPUD during the study period. Forty-five (75.0\%) patients gave significant history of NSAIDs use, of which nine (20.0\%) had medical prescription, while others were over the counter medications. None of the patients was on ulcer prophylaxis including those who were on long term use and with prior dyspeptic symptoms. Five patients (11.1\%) were on the recommended dose of the NSAIDs, thus patients in this series showed irrational use of NSAIDs. Forty-two (93.3\%) patients had gastric perforation, while only three of the patients had duodenal perforation. The association between significant NSAIDs use and gastric perforation was found to be significant $(p=0.002)$. There was no difference in the site of perforation when patients who were on long term NSAIDs were compared with short term NSAIDs use (10.0 vs. 35.0$)(p=0.061)$. In addition, long term NSAIDs use $(p=0.041)$, ignorance of proper dose of the medication $(p=0.003)$, and gastric ulcer perforations $(p=0.011)$ were independent causes of mortality in the studied patients when age and duration of the presentations were matched.
\end{abstract}

Conclusion: NSAIDs use, including both long- and short-term use, was significant among patients with gastric perforation.

Keywords: Perforated peptic ulcer, Gastric ulcer, NSAIDs

Cite this article as: Egwuonwu $\mathrm{O}$, Chinedu $\mathrm{O}$, Chianakwana G, Anyanwu S, Emegoakor C, Nzeako H. Changing pattern of perforated PUD: Are NSAIDs to be blamed? Turk J Surg 2019; 35 (2): 105-110

\section{Corresponding Author}

Okoli Chinedu

E-mail: eduokoli@yahoo.com

Received: 28.03.2018

Accepted: 18.05 .2018

Available Online Date: 13.06.2019

OCopyright 2019 by Turkish Surgical Society Available online at www.turkjsurg.com

DOI: $10.5578 /$ turkjsurg.4145

\section{INTRODUCTION}

Globally, 4 million people suffer from peptic ulcer diseases (PUD) annually. Ten twenty percent of these cases are complicated and $2-10 \%$ of these ulcers perforate (1). Though uncomplicated PUD can be generally managed medically, perforated peptic ulcer disease (PPUD) is a life-threatening condition which requires emergency intervention. Though conservative approach to management has been described by Taylor, most of these patients are treated surgically using open repair or laparoscopic repair depending on expertise $(2,3)$. With progressive negative decline of definite acid reducing surgeries, most of these patients have primary repair with or without omental patch and triple therapy. Biopsy is added in case of stomach perforations.

Alhough duodenal perforations are more commonly reported, it appears that the dynamics of the socio-demographics of patients with PPUD depends on the region studied $(4,5)$. In the West, duodenal perforation is more common and generally confined in the elderly population who are on ulcerogenic drugs, 1 while among the Orientals in Japan, gastric perforations are more due to increased incidence of gastric malignancy (6). Most reports from our environment suggest that perforated duodenal ulcer is more common than gastric perforations and that patients with former pathology are generally younger than the latter $(4,5)$. Exposure to Helicobacter pylori infection and use of non-steroidal anti-inflammatory drugs (NSAIDS) are the most common risk factors predisposing to PPUD, other factors include alcohol, smoking, stress and use of crack cocaine (7). However, it is difficult to blame 
one risk factor as the cause of PPUD in a patient because most patients have more than one risk factors. In our environment, abuse of NSAIDs among different age groups is increasingly being recognized. These medications are readily available without prescription for various indications. These medications are commonly used for relieve of body aches, arthritic pains, and as part of medications for cardiovascular diseases. Patients on NSAIDs including aspirin are at increased risk of having adverse gastrointestinal events $(7,8)$.

Based on the observation of unusual upsurge in the number of gastric perforations in our practice in contrast to other reports from other centers in Nigeria, the authors decided to investigate if there is any association between the increased incidence of gastric perforation in our patients with NSAIDs use $(4,5,9)$.

\section{MATERIAL and METHODS}

The data were collected retrospectively from 2011 to May 2015 and then prospectively until December 2017. Adults with clinical suspicion of perforated peptic ulcer diseases were referred from nearby primary and secondary health facilities. On presentation at the accident and emergency department of the hospital, the patients were evaluated and resuscitated with intravenous fluid, electrolytes, and blood transfusion as appropriate. They were sent for chest radiograph for the presence of air under the diaphragm.

The patients were then counseled for both surgery as well as inclusion into the study. All patients who consented to surgery were moved to the theatre. All of the patients underwent emergency exploratory laparotomy through a midline incision, with primary repair of the perforation and addition of omental patch in cases of duodenal perforation. Peritoneal lavage was usually done with a minimum of 5 liters of warm normal saline. The ulcer edges were biopsied in all patients with gastric perforations. The following data were entered into a structured proforma; age, sex, initial site of pain, mode of onset of pain, previous history of PUD, use of NSAIDs, smoking, alcohol intake, site of ulcer, type of repair, suture used, post-operative complications, length of hospital stay, and outcome of treatment. Patients in the retrospective group who did not have intra-operative diagnosis or incomplete data were excluded. Only 60 patients who had intra-operative finding of perforated gastric or duodenal ulcer were included into this study. Patients were initially managed at the intensive care unit (ICU) before being moved to the ward. Patients were grouped into different categories based on

I. Recent use of NSAIDs and no recent use.

II. Long term NSAID use (more than 4 weeks) and Thos who had recent significant intake of NSAIDS (daily consumption of NSAIDs in past 3 weeks) .

II. Patients took NSAIDs based on medical prescriptio and those who did not have any prescription (uknown dose).
IV. Patients who were on recommended dose of NSAIDs and patients who did not.

The study was carried out at no extra cost to the eligible patients who gave their informed consent. There was strict observation of the patients' confidentialities by using codes in place of names for reference, analysis and presentation of the results of this study. This study adhered to the tenets of the declaration of Helsinki for research in humans.

Data were analyzed using Statistical Package for Social Sciences (IBM SPSS statistics for Windows version 21.0. Armonk, NY: IBM Corp). Results of categorical variables were expressed using tables and charts where appropriate while continuous data were expressed using mean and standard deviations, where appropriate. Associations between categorical data were determined using the Pearson Chi square test or Fishers Exact test were appropriate. Independent $\mathrm{T}$ test was used to determine the mean difference between continuous data. Statistical significance was inferred at $p$ value of $<0.05$.

\section{RESULTS}

A total of 60 patients had intra-operative diagnosis of PPUD during the study period. Forty-one males and nine females made up the study population giving a ratio of 5.2:1 . Mean age (standard deviation) of the study population was 47.74 (16.08) years; age ranged from 21-80 years. The duration of symptoms before presentation ranged from 2 hours to 2 months. The first symptom in all patients was abdominal pain. Most of the patients felt pain at the epigastrium and described the onset of the pain as sudden (66.0) (Table 1). Fifty percent of the patients agreed to previous history of dyspepsia while $10.0 \%$ of the patients could not remember such symptoms, while $40 \%$ of the patients denied any prior history of dyspepsia. None of these patients had undergone upper gastrointestinal endoscopy before presentation but 9 patients had had PUD diagnosis by a clinician.

The sites and sizes of the perforations were noted (as shown in Table 2). None of the patients had definitive acid reducing surgery. Only $14.0 \%$ of the patients had drain inserted. Thirty-four percent of the patients died while $51.5 \%$ of the remaining patients developed complications which were treated, and the patients were later discharged (see Table 2 for details).

Significant NSAIDs use was common among the 45 (75.0\%) patients who were studied, only nine patients (20.0\%) had NSAIDs prescribed by medical personnel, while the rest got the medications from patent medicine dealers. None of the former was on either proton pump inhibitor nor Histamine type 2 blockers. Only five patients (11.1\%) were on the recommended dose of the NSAIDs, thus patients in this series showed irrational use of NSAIDs. Forty two (93.3\%) patients had gastric perforation, while only three of the patients had duodenal perforation. The association with significant NSAIDs use and gastric perforation 


\begin{tabular}{|c|c|c|c|c|}
\hline Patient characteristics & Gastric & Duodenum & & \\
\hline \multicolumn{5}{|l|}{ Age distribution (in years) } \\
\hline $21-30$ & 9 & 3 & 20.0 & \\
\hline $31-40$ & 7 & 2 & 15.0 & \\
\hline $41-50$ & 8 & 1 & 15.0 & \\
\hline $51-60$ & 15 & 5 & 33.330 & \\
\hline $61-70$ & 6 & 1 & 11.67 & \\
\hline $71-80$ & 3 & 0 & 5.0 & \\
\hline Mean age & $47.90 \pm 16.34$ & $46.88 \pm 15.67$ & & 0.870 \\
\hline \multicolumn{5}{|l|}{ Mode of onset } \\
\hline Sudden & 31 & 12 & 66 & 0.001 \\
\hline Insidious & 16 & 1 & 34 & \\
\hline Prior history of dyspepsia $(n=25)$ & 21 & 4 & & 1.000 \\
\hline Previous diagnosis of PUD $(n=9)$ & 7 & 2 & & 0.631 \\
\hline \multicolumn{5}{|l|}{ Site of initial pain $(n=50)$} \\
\hline Epigastric & 38 & 11 & & \\
\hline Right lower quadrant & 6 & 1 & & \\
\hline Central & 2 & 1 & & \\
\hline Generalized & 1 & - & & \\
\hline \multicolumn{5}{|l|}{$\operatorname{Sex}(n=50)$} \\
\hline Male & 37 & 10 & 84 & 1.000 \\
\hline Female & 9 & 3 & 16 & \\
\hline Smoking $(n=8)$ & 5 & 3 & 2 & 0.120 \\
\hline Alcohol & 29 & 4 & 27 & 0.376 \\
\hline NSAIDs $(n=45)$ & 42 & 3 & 13 & 0.002 \\
\hline Mean duration of symptoms & $47.84 \pm 18.34^{*}$ & $43.71 \pm 14.39$ & & 0.540 \\
\hline \multicolumn{5}{|c|}{$\begin{array}{l}\text { * One patient presented after } 2 \text { months of onset of symptoms and was excluded being an outlier. } \\
\text { PUD: Peptic ulcer diseases. } \\
\text { NSAIDs: Non-steroidal anti-inflammatory drugs. }\end{array}$} \\
\hline
\end{tabular}

was found to be significant ( $p=0.002$ ) (Table 3 ). There was no difference in the site of perforation when patients who were on long term NSAIDs were compared with short term NSAIDs use (10.0 vs. 35.0) ( $p=0.061)$. In addition, long term NSAIDs use ( $p=$ $0.041)$, ignorance of proper dose of the medication $(p=0.003)$, and gastric ulcer perforations $(p=0.011)$ were independent causes of mortality in the studied patients when age and duration of the presentations where matched. Furthermore, mean age of the patients that died was significantly more than the mean age of the surviving patients $(p=0.019)$. Smoking and alcohol abuse were not significantly associated with death $(p=0.438$ and $p=$ $0.100)$ respectively.

\section{DISCUSSION}

PPUD is a common cause of peritonitis in our center with an average of 10 cases undergoing operative treatment per year.
In our study, more males were affected, which concurred with other reports in the literature $(1,4,5,9,10)$. Some of the speculated reasons for the high incidence of PPUD amongst males in our environment may be due to smoking and excessive alcohol consumption prevalent amongst this gender. Though the average age of patients in our series was similar to the mean age reported by other authors in other centers in Nigeria $(4-5,9)$ it was generally lower than the mean age seen in western clime where the majority of the patients are above 60 years of age and the incidence of perforated PUD is found to be higher in females taking ulcerogenic drugs $(1,11)$.

Most of our patients presented with acute onset epigastric pain which later became generalized while only few patients reported insidious onset pain. The former is so classical of PPUD, such that Edward Crisp who was the first to report 50 cases of PPUD 
Table 2. Operative characteristics of the patients

\begin{tabular}{|c|c|c|c|}
\hline \multirow[t]{2}{*}{ Operation characteristics } & \multirow[b]{2}{*}{ Gastric perforation } & \multirow[b]{2}{*}{ Duodenum perforation } & $\mathbf{p}$ \\
\hline & & & \\
\hline \multirow{2}{*}{\multicolumn{4}{|c|}{$\begin{array}{l}\text { Intra-operative findings } \\
\text { Site of perforation }(n=60)\end{array}$}} \\
\hline & & & \\
\hline Antrum & 32 & - & \\
\hline Body of stomach & 15 & - & \\
\hline First part of duodenum & - & 13 & \\
\hline \multicolumn{4}{|l|}{ Size of perforation } \\
\hline Mean size of perforation & $2.03 \pm 1.67$ & $1.50 \pm 1.22$ & $0.573^{* *}$ \\
\hline \multicolumn{4}{|l|}{ Suture for closure $(n=48)$} \\
\hline Silk & 6 & 1 & \\
\hline Delayed absorbable (polyglycolic acid) & 34 & 7 & \\
\hline \multicolumn{4}{|l|}{ Post-operative findings } \\
\hline Mean hospital stay & $12.39 \pm 2.61$ & $8.1 \pm 2.87$ & $0.998^{* *}$ \\
\hline Complications* $(n=38)$ & & & - \\
\hline Surgical Site Infection & 7 & 2 & \\
\hline Entero-Cutaneous fistula & 1 & 1 & \\
\hline Peritoneal abscess & 2 & - & \\
\hline Burst abdomen & 1 & - & \\
\hline Acute kidney injury & 1 & - & \\
\hline Intestinal obstruction & 1 & - & \\
\hline Death $(n=22)$ & 17 & 3 & \\
\hline
\end{tabular}

Table 3. Categorization of patients on NSAIDs

\begin{tabular}{|l|c|c|c|}
\hline Type of perforation & Use of NSAIDs & No recent history of NSAIDs & p* \\
\hline Gastric & $42(70.0)$ & $5(8.33)$ & 0.002 \\
\hline Duodenal & $3(5.0)$ & $10(16.67)$ & Long term \\
\hline Gastric & Significant use in the last 2 weeks & $8(17.8)$ & 0.061 \\
\hline Duodenal & $34(75.56)$ & $2(4.44)$ & 0.041 \\
\hline & $1(2.22)$ & Over the counter prescription & 35 \\
\hline Gastric & Medically prescribed & 1 & 38 \\
\hline Duodenal & 7 & Takes it based on personal discretion & \\
\hline & 2 & 2 & 0.032 \\
\hline Gastric & Recommended dose & & \\
\hline Duodenal & 4 & & \\
\hline * Fishers Exact tests. \\
NSAlDs: Non-steroidal anti-inflammatory drugs.
\end{tabular}


and accurately summarized the clinical aspects of perforation, concluded that: 'The symptoms are so typical, I hardly believe it is possible that anyone can fail to make the correct diagnosis' (12).

In our series, there was more gastric perforations than duodenal perforation, which is a reverse in the trend documented in the literature in our environment $(4,5)$. though a rising incidence of gastric ulcers has been reported by Ndububa et al., at Ile-ife, Osun state in which there was similar incidence of duodenal and gastric ulcers (9). Our series showed similar trend found among the orientals with high incidence of malignant gastric ulcers, however, all histology reports in our series were benign (6). Furthermore, it was observed that $75.0 \%$ (45) of the patients in our series had recent history of ingestion of NSAIDS, a common over the counter medications. Seventy percent (42) of the patients with PPUD had gastric perforation while only 3 (5\%) had duodenal perforations. Of the 42 patients who had gastric perforation, 35 (77.8) patients had significant intake in the last 2 weeks. Most of the patients on NSAIDs (80.0\%) bought the medication over the counter without prescription. It was difficult for us to compare our findings with other studies in our environment on PPUD because of the peculiar high prevalence of perforated benign gastric ulcers in our series. However, one can deduce that irrational use of NSAIDs was common among our studied subjects. NSAIDs are one of the etiological factors of PUD, they act by inhibiting the COX II enzyme there by limiting the gastro-protective effective of this enzyme (7). This observation of high intake of NSAIDs in our study suggests the need for further systematic research to determine the exact role of these medications in causing gastric perforations. Only 10.0\% (6) and 6.0\% (4) of the patients agreed to taking alcohol above the recommended limits of 14 units, and smoking respectively. Studies have shown that the deleterious effect of NSAIDs on gastric mucosa has synergistic effect in the presence of Helicobacter pylori infection, alcohol and smoking $(1,13)$. interestingly, duodenal perforations in our series were exclusively found in females. No particular reason could be suggested for this finding.

Furthermore, our series showed high mortality rate particularly in patients who presented with gastric perforations with no recorded case of mortality in patients with duodenal perforation. Post-operative complications were also higher in patients in the gastric perforation group. Only 20.0\% (10) of the patients in our study presented within 12 hours of onset of symptoms. Some authors have suggested that delaying the time point of operation beyond $12 \mathrm{~h}$ after the onset of clinical symptoms would worsen the outcome in PPUD $(2,14)$. Though delayed presentation is one of the factors blamed for high mortality rate, there was no significant difference in the time for presentation and size of perforation both group of patients (gastric or duodenal perforation) however, patients with gastric perforation were more likely to die if they presented after 12 hours of onset of symptoms (15). Besides delayed perforation, our study showed that older age,and use of NSAIDs were significantly associated with mortality while duodenal perforations were not. Smoking and alcohol abuse were also not significantly associated with mortality in our study. Our mortality rate was higher than that reported by Ugochukwu et al. and Nuhu et al $(4,5)$. There was no case of gastric perforation in both studies. No reason could be suggested for the high mortality rate of gastric perforations more than duodenal perforations. Probably the degree of inflammatory response due to the acidic content and volume of fluid produced in the stomach and following gastric perforation cause extensive irritation of the peritoneal cavity hence exaggerated systemic inflammatory response.

Finally, we recorded 2 cases of spontaneous closure of PPUD and one case of failed conservative management after 2 months of treatment in a private hospital in a patient who had gastric perforations. All three patients were explored because of persistent fever, abdominal pain and ileus. This further strengthens the role of surgery in management of patients with PPUD. Taylor had described non operative management of PPUD in selected group of patients, these findings in our study suggest that this may not be readily applicable in our setting where most of the patients present late (2).

This study had some limitations including the inability to determine the exact dose of NSAIDs and the brand consumed by the patients because most of the patients could not recollect this information during the pre-operative evaluation.

In conclusion, gastric perforations were more common in our series with both high mortality and post-operative complication rates more than duodenal perforations. Significant use of NSAIDs was associated with gastric perforations which were less common in other studies in our environment. NSAIDs use or prescription should be guided and administered with proton pump inhibitors or Histamine type 2 blockers.

Ethics Committee Approval: This study was approved by the ethical board of Nnamdi Azikiwe University Teaching Hospital.

Informed Consent: Written informed consent was obtained from patients who participated in the prospective part of the study. The data from the retrospective patients were de-identified so no consent was needed.

Peer-review: Externally peer-reviewed.

Author Contributions: Consept - O.E.; Design - C.O.; Supervision - G.C., S.A.; Resource - O.E.; Materials - C.E.; Data Collection and/or Processing - C.O., H.N.; Analysis and Interpretation - C.O.; Literature Search - C.O.; Writing - C.O.; Critical Reviews - G.C., S.A.

Conflict of Interest: Authors do not have any conflict of interest.

Financial Disclosure: The authors declared that this study has received no financial support. 


\section{REFERENCES}

1. Svanes C. Trends in perforated peptic ulcer: incidence, etiology, treatment, and prognosis. World J Surg 2000; 24: 277-83. [CrossRef]

2. Keane TE, Dillon B, Afdhal NH, McCormack CJ. Conservative management of perforated duodenal ulcer. Br J Surg 1988; 75: 583-4. [CrossRef]

3. Mouret $P$, François $Y$, Vignal J, Bartht $X$, Lombard-Platet R. Laparoscopic treatment of perforated peptic ulcer. Br J Surg 1990;77: 1006. [CrossRef]

4. Ugochukwu Al, Amu OC, Nzegwu MA, Dilibe UC. Acute perforated peptic ulcer: on clinical experience in an urban tertiary hospital in south east Nigeria. Int J Surg 2013; 11:223-7. [CrossRef]

5. Ameh EA, Nnamdi PT. Pattern of peptic ulcer disease in Zaria, Nigeria East Afr Med J 1998; 75: 90-2.

6. Kawai K, Shirakawa K, Misaki F, Hayashi K. Natural history and epidemiologic studies of peptic ulcer disease in Japan. Gastroenterology 1989; 96: 581-5. [CrossRef]

7. Kitagawa Y, Dempsey D. Stomach. Brunicardi CF, editor. Schwartz's principles of surgery. 10th ed. New York: Mc Graw-Hills Educational; 2015.

8. Mahvi D, Krantz SB. Stomach. Townsend Jr MC, Beauchamp RD, Evers BM, Mattox Keditors. Sabiston Textbook of Surgery. $19^{\text {th }}$ ed. USA: Saunders; 2012.
9. Ndububa DA, Adeyemi OJ. Peptic ulcer disease in Nigeria. IFEMED J 2008:62-6. [CrossRef]

10. Dodiyi-Manuel A, Wichendu PN, Enebeli VC. Presentation and management of perforated peptic ulcer disease in a tertiary centre in South South Nigeria. J West Afr Coll Surg 2015; 5: 36-48.

11. Bertleff MJ, Lange JF. Perforated peptic ulcer disease: a review of history and treatment. Dig Surg 2010; 27: 161-9. [CrossRef]

12. Griffin MR, Piper JM, Daugherty JR, Snowden M, Ray WA. Nonsteroidal anti-inflammatory drug use and increased risk for peptic ulcer disease in elderly persons Ann Intern Med 1991; 114:257-63. [CrossRef]

13. Lau WY, Leow CK. History of perforated duodenal and gastric ulcers. World J Surg 1997; 21: 890-6. [CrossRef]

14. Zittel TT, Jehle EC, Becker HD. Surgical management of peptic ulcer disease today: indication, technique and outcome. Langenbecks Arch Surg 2000; 385: 84-96. [CrossRef]

15. Hill AG. Management of perforated duodenal ulcer. Holzheimer RG, Mannick JA, editors. Munich: Zuckschwerdt; 2001.

\section{ORIJINAL ÇALIŞMA-ÖZET}

Turk J Surg 2019; 35 (2): 105-110

\section{Perfore peptik ülser hastalığında değişen durum: NSAii suçlanabilir mi?}

\section{Ochonma Egwuonwu' ${ }^{1}$ Okoli Chinedu ${ }^{1}$, Gabriel Chianakwana ${ }^{1}$, Stanley Anyanwu ${ }^{1}$, Chiemelu Emegoakor ${ }^{1}$, Henry Nzeako ${ }^{1}$}

${ }^{1}$ Nnamdi Azikiwe Üniversitesi Eğitim Hastanesi, Cerrahi Bölümü, Nnewi, Nijerya

\section{ÖZET}

Giriş ve Amaç: Bu çalışmanın amacı, perfore peptik ülser hastalığı (PPÜH) sebebiyle başvuran hastalarda gastrik perforasyon ve nonsteroid antiinflamatuvar ilaç (NSAii) kötüye kullanımı ile arasında bir ilişki olup olmadığını belirlemekti.

Gereç ve Yöntem: Veriler, Mayıs 2011 ve Mayıs 2015 tarihleri arasında retrospektif ve Aralık 2017'ye kadar da prospektif olarak toplandı. Eksploratoris laparotomi ile PPÜH tanısı alan 60 hasta çalışmaya dahil edildi. Veriler SPSS 21.0 kullanılarak analiz edildi ve $p$ değeri $\leq 0,05$ istatistiksel olarak anlamlı kabul edildi.

Bulgular: Çalışma dönemi içerisinde toplam 60 hasta PPÜH için opere edildi. Kırk beş (\%75) hasta NSAil kullanım öyküsü belirtti. Bu hastalardan dokuzunun tıbbi reçetesi varken, diğerleri reçetesiz satılan ilaçlardan oluşmaktaydı. Uzun dönem kullananlar ve daha önce dispeptik belirtiler gösterenler dahil olmak üzere hastaların hiçbiri ülser profilaksisi kullanmamaktaydı. Beş $(\% 11,1)$ hasta NSAil'nin tavsiye edilen kullanım dozunu aşmamıştı, bu yüzden bu serideki hastalar NSAii irrasyonel kullanımı ile ilişkiliydi. Kırk iki $(\% 93,3)$ hastada mide delinmesi varken sadece üç hastada duodenal delinme mevcuttu. Büyük ölçüde NSAil kullanımı ile mide delinmesi arasındaki ilişki anlamıydı $(p=0,002)$. Uzun dönem ve kısa dönem NSAil kullanımı karşılaştııılığında, delinme yeri açısından anlamlı bir fark bulunmadı $(10,0$ vs. 35,0$)(p=0,061)$. Ayrıca, yaş ve başvuruların süresi eşleştiğinde uzun dönem NSAii kullanımı $(p=0,041)$, ilacın doğru dozu hakkındaki bilgi eksikliği $(p=0,003)$ ve gastrik ülser delinmesi $(p=0,011)$ çalışılan hastalarda bağımsız mortalite sebepleri arasındaydı.

Sonuç: Hem uzun hem kısa dönem kullanımı dahil NSAii kullanımı mide delinmesi olan hastalarda anlamlıydı.

Anahtar Kelimeler: Perfore peptik ülser, gastrik ülser, NSAil

Doi: $10.5578 /$ turkjsurg.4145 